\title{
A study on the relationship between capital structure and the performance of production market: A case study of firms listed on Tehran Stock Exchange
}

\author{
Kobra Sadat Salek Esfahani* and Mohammad Ali Ghasanfarymojarad
}

Department of Management and Accounting, Kashan Branch, Islamic Azad University, Kashan, Iran

\section{H R O N I C L E}

Article history:

Received October 27, 2012

Received in revised format

29 January 2013

Accepted 18 February 2013

Available online

February 202013

Keywords:

Capital Structure

Return on Assets

Sales Growth

Debt ratio

Profit Risk

\section{Introduction}

The industrial and financial economists have found increasingly that the capital structure of a company might be associated with the behavior of its production market (Brander \& Lewis, 1986; Showalter 1995 - 1999). Many also have found that the financial activities of firms may not be performed necessarily internationally, rather domestically based on the culture of the related country, its legal system, institutions, and progress phases (Brander, 2007). Therefore, there are some attempts to analyze the special effects of a country on the relationships between the performance of production market and financial leverage. Opler (1994), Titman (2003), and Campello (2006 \& 2007) conducted various studies on the impacts of the performance of production market on debt. In this research, we continue the works presented by Campello (2006) on the relation between production market and

Corresponding author.

E-mail: ksalek1362@gmail.com (K. S. Salek Esfahani)

(C) 2013 Growing Science Ltd. All rights reserved. doi: 10.5267/j.msl.2013.02.015 
capital structure in a developing country, i.e. Iran. Decisions on financing and investment of companies are made foresightedly. The financing sources of companies are classified into two groups of internal and external financial sources based on their financing policies. In internal financing method, companies constitute their financial source out of their earned profit based on external financing method, out of debts and shares.

Companies issue securities normally in two types of debt and equity securities, and it is required to know that the most risky securities are debt securities, since the issuing company is required to pay its debt together with its interests at the maturity date. In case of failure in meeting the obligation in a timely manner, the company may be forced to dispose its assets. Moreover, equity securities (ordinary shares) are less risky for the company, since the company is not required to repay the dividends at the maturity date, and it can pay the dividends after meeting obligations. Therefore, the question is how companies can finance to influence the profit, return on equity, and sales, positively.

There are various factors including the nature of activities, assets, and type of industry, which influence the financing of a company. For instance, the nature of the activities conducted in a company may be so that allows to manage business based on cash flows. In such circumstances, the use of debts instead of shares (financing by debts) costs less money than shares do, and it boosts the profits of the company.

\section{Theoretical framework and review of literature}

The theory we are most closely testing is based on the work by Brander and Lewis (1986), where it tries to investigate the relationship between financial decisions and product-market decisions. Previous literature had analyzed these decisions separately by assuming an oligopolistic market, Brander and Lewis demonstrated (1986) that a limited liability firm that uses debt may choose to trade more aggressively by increasing its output. Such a strategy increases returns for shareholders when the firm is doing well. When the firm is doing poorly, shareholders are indifferent because debt holders have the prior claim on the firm's assets in the event that the firm becomes bankrupt. Subsequent theory extends and in some cases contradicts the findings of Brander and Lewis. For instance, Bolton and Scharfstein (1990) argued that a firm that relies too much on external financing would become more vulnerable on markets fluctuations. The firm may, therefore, choose to employ internal sources of financing. Chen et al. (2007) argued that firms, which delay the introduction of products, and are more indebted than industry rivals, will be placed at a competitive disadvantage. Key empirical papers by Chevalier (1995a, b), Phillips (1995), and Kovenock and Phillips (1995, 1997) tended to contradict Brander and Lewis. Chevalier (1995a, b) examined some evidence from the American supermarket industry in the 1980s. They reported that announcements of leveraged buyouts (LBOs) by supermarkets could increase the expected returns of rival firms in the same locality and encourage entry and expansion by rivals. There is also a higher probability that a firm will exit its local market following its LBO if prices fall. Phillips (1995) examined four United States industries and reported mostly that higher leverage encourages firms to undertake fewer investment opportunities and to behave less aggressively. Kovenock and Phillips $(1995,1997)$ demonstrated that firms in highly concentrated industries that increase their debt are more likely to close down plants and reduce plant investment. If the market share of these leveraged firms is high, rival firms are less likely to close plants. When firms are highly leveraged, rival firms are also more likely to increase their investment.

Other aspects of product markets may be associated with leverage. For instance, Low and Chen (2004) found that product diversification allows firms to implement more leverage, because it lowers their exposure to risk. Characteristics of debt may also be associated with product market behavior. For example, Glazer (1994) argued that the way firms compete in product markets depends on whether they were using long-term debt, short-term debt, or no debt. The author stated that if firms are competing on the basis of output, the use of long-term debt would tend to encourage collusion between the firms. 
Apart from the various results on the predicted relationships between leverage and product marketcompetition and performance, important methodological issues have arisen in the literature. Zingales (1998) stated that efficient trucking firms are more likely to survive deregulation of their industry. Firms that under-invest because of higher leverage are less likely to survive. As in previous studies, Zingales employed regression analyses to test the relationship between debt and product-market competition. However he claimed that his results were more robust than those presented by Chevalier (1995a, b), Phillips (1995), and Kovenock and Phillips (1997). In these studies, it is possible that a firm's financing choices are made in anticipation of their impact on its competitive position. Therefore, it is difficult to determine whether financing choices impact a firm's competitive position or vice versa. The causal relationship is clearer in Zingales, because deregulation was an external event that unexpectedly affected competition and capital structure choices in the trucking industry. Istaitieh and Rodriguez $(2002,2003)$ implemented a simultaneous regression equations model to deal with the issue of cause and effect. In one equation, debt is the dependent variable, while product market factors are included as independent variables. In the other equation a key product market factor is specified as the dependent variable and debt is included as one of the independent variables. Using data from Spanish manufacturing firms, the authors find that industry concentration and product market competition both influence and were influenced by leverage.

Our paper's empirical model is most similar to that of Opler and Titman (1994) and Campello (2003, 2006, 2007), in that it examines the relationship between a firm's capital structure and its performance, relative to the performance of its competitors in the same industry. Opler and Titman (1994) looked at the relationship between financial distress and corporate performance. They found that during recessions, highly indebted firms lose business to their less indebted rivals. Highly leveraged firms that spend significant amounts of money on research and development are more liable to lose market share during difficult economic periods. This is because such firms are producing specialized products, and this makes them particularly susceptible to financial distress. Campello (2003) found that during economic downturns, highly indebted firms experience a significant decline in their sales growth in industries in which their competitors are less indebted. This outcome is not observed if all firms in an industry are highly leveraged. Campello believed his study was the first to find evidence of a relationship between capital structure, product markets and business cycles, and that the evidence indicates that capital structure systematically affects firms' performance in the marketplace. Campello (2006) found that firms with significantly higher longterm debt than the industry average could experience sales growth as they take on debt at the margin. However, firms with very high levels of debt in comparison to the industry standard may experience no gains in market share, or even losses. The study also found that market leader firms in concentrated industries did not do as well as their competitors when their debt levels exceed the industry average. In the same industries, less indebted leader firms increase their market share as they take on more debt. Campello (2007) found that when a firm's investments were funded with debt and the firm's assets are observed to be more tangible after the debt has been raised, the firm's productmarket performance is better than that of its rivals. Namazi and Shirzadeh (2005) stated in their studies that there was in general a positive relationship between capital structure and return on assets of companies, but such a relationship was statistically weak. As the relation between capital structure and capital depends on the type of industry, therefore, the optimal structure should be searched among different industries.

The results of the studies of Norawesh and Yazdani (2010) showed that there was a significant and negative relationship between leverage and investment. Moreover, the results confirmed that the relationship between leverage and investment in companies with lower growth opportunities was stronger than that in the companies with higher growth opportunities. 


\section{Research Hypotheses}

\section{Main Hypothesis}

There is a relationship between capital structure and production market.

\section{Sub Hypotheses}

Hypothesis 1: there is a relation between debt ratio and sales growth.

Hypothesis 2: there is a relation between debt ratio and return of equity (ROA).

\subsection{Statistical population and research sample}

The statistical population of this research consists of the companies listed on TSE over the period 2005-2010 with following conditions:

1- The companies had been listed on the stock exchange from 2005 to 2010.

2- Their fiscal year ended to March 14 of each year.

3- Their activity was not of investment type.

4- Their fiscal information for the period from 2005 to 2010 was provided completely.

Based on the above-mentioned conditions, 216 companies were considered as qualified for this research, and according to the sampling calculations, 128 companies were sampled. For the purpose of stratified random sampling or stratification, samples were taken from each stratum by drawing lots using domain of numbers or defined codes, to select the members corresponding to the allotted code in each stratum. In conclusion, the members of the sample were selected from the different industries.

\subsection{General Method of Research}

This is an applied research in terms of objective and used an ex post facto method for its design, and an inductive- descriptive technique for the collection of data and inference.

\subsection{Data Collection Techniques}

For the collection of data based on library method, foreign and domestic researches published in books, papers, and dissertations were used. The information of the researched companied were collected from the information published by Tehran Stock Exchange and its internet site www.rdis.ir.

\subsection{Statistical Methods}

In this research, two statistical methods have been applied:

Descriptive Method: at first, numerical characteristics and ratios are used to describe the sample or statistical population demographically. Thereafter, main variables are described using scatter diagram and numerical characteristics (such as mean, variance, standard deviation, skewness, kurtosis, maximum, and minimum).

Analytical Methods: the following methods are used in two parts. At first, the presumptions of multivariate linear regression set forth in the following are evaluated, to find out if:

- The coefficient of determination tends to zero,

- The data of the research are normal according to the Kolmogrov - Smirnov test.

- The linear independence of independent variables is conducted by Pearson correlation test.

- $\quad$ The data are not auto-correlated according to Durbin-Watson test and LM test.

- The homogeneity of variances is evaluated by White test.

In the second phase, the significance of the correlation coefficient equation and its parameters is tested. For this purpose, the linearity and correlation tests are conducted. 


\subsection{Research Model}

$\mathrm{Y}=\mathrm{f}\left(\mathrm{x}_{1}, \mathrm{x}_{2}, \mathrm{x}_{3}, \mathrm{x}_{4}, \mathrm{x}_{5}\right)$

$\mathrm{Y}=$ dependent variable $=\mathrm{Y}_{\mathrm{it}}$

Dependent variable: debt ratio $=$ total debt/total assets

$\mathrm{x}_{1}=$ first independent variable $=$ sales growth

Sales growth:

changes in the sales of company (sales of the year ${ }_{t}$ - sales of the year ${ }_{t-1}$ )/sales of the year $t_{t-1}$

$\mathrm{x}_{2}=$ second independent variable $=\mathrm{ROA}$

Return on equity: the previous earnings before tax and interest (EBIT) divided by the book value of the assets.

$\mathrm{X}_{3}=$ third independent variable $=$ profit risk

Profit risk: average absolute value of EBIT/the standard deviation of EBIT

$\mathrm{x}_{4}=$ fourth independent variable: size of firm

Size of company: the natural logarithm of total assets at the end of the fiscal year

Table 1

The Variables and their Calculation Method

\begin{tabular}{|c|c|c|}
\hline Variable & Symbol & Definition \\
\hline Capital Structure & DR & Debt ratio $=$ total debts/total assets \\
\hline Return on Assets & ROA & EBIT/the book value of total assets \\
\hline Sales Growth & SG & (the sales of the year $r_{t}$ the sales of the year $t_{t-1}$ )/sales of the year $t-1$ \\
\hline Size of Firm & SIZE & LN (total assets) \\
\hline Profit risk & RISK & The standard deviation of operating profit/book value of total assets \\
\hline
\end{tabular}

$\mathrm{f}=$ the mathematical relation between dependent variable (debt ratio) and independent variables $\mathrm{x}_{1}$, $\mathrm{x}_{2}, \mathrm{x}_{3}, \mathrm{x}_{4}$, and $\mathrm{x}_{5}$. This relation is calculated using multivariate linear regression as follows (Fixed effect method):

$Y_{i t}=\alpha+\beta x_{i t}+\varepsilon_{i t}$

\section{Findings of Research}

In this research, the statistical sample includes 128 companies for the period from 2005 to 2010. To test the hypotheses, the cross-sectional data and panel data are consolidated.

Table 2

Kolmogrov - Smirnov Test of the Research Logarithm

\begin{tabular}{|c|c|c|c|c|c|c|c|c|}
\hline $\begin{array}{l}\text { Research } \\
\text { Variables }\end{array}$ & No. & Mean & $\begin{array}{c}\text { Standard } \\
\text { Deviation }\end{array}$ & $\begin{array}{c}\text { Absolute Value of } \\
\text { the highest Standard } \\
\text { Deviation }\end{array}$ & $\begin{array}{c}\text { Highest Positive } \\
\text { Standard } \\
\text { Deviation } \\
\end{array}$ & $\begin{array}{l}\text { Highest Negative } \\
\text { Standard Deviation }\end{array}$ & $\begin{array}{l}\text { Kolmogrov - } \\
\text { Smirnov Test }\end{array}$ & $\begin{array}{l}\text { Sig. } \\
\text { Statistic }\end{array}$ \\
\hline Debt Ratio & 497 & 0.8746 & 3.43105 & 0.57 & 0.57 & -0.43 & 1.274 & 0.081 \\
\hline Sales Growth & 764 & 0.0203 & 0.53130 & 0.130 & 0.130 & -0.085 & 3.607 & 0.1314 \\
\hline Return on Assets & 757 & 0.0468 & 0.13474 & 0.075 & 0.075 & -0.065 & 2.072 & 0.182 \\
\hline Profit Risk & 512 & 0.587 & 2.71054 & 0.396 & 0.360 & -0.396 & 8.954 & 0.074 \\
\hline Size & 767 & 13.1194 & 1.48071 & 0.75 & 0.75 & -0.61 & 2.088 & 0.141 \\
\hline
\end{tabular}

Since the significance level (sig) for the logarithm of variables is greater than $5 \%$ (and as the null hypothesis is rejected because the significance level is lower than $5 \%$ ), therefore, we conclude that the variables of this research are distributed normally. Pearson coefficient of the correlation between dependent and independent variables have been provided in the Table 3. 


\section{Table 3}

The results of Pearson correlation ratios

\begin{tabular}{|c|c|c|c|c|c|c|}
\hline & & $\begin{array}{c}\text { Lag } \\
\text { volatility }\end{array}$ & size & Lag Sales growth & lag RoA & Lag debt \\
\hline \multirow{2}{*}{$\begin{array}{c}\text { Lag } \\
\text { volatility }\end{array}$} & Pearson Correlation & 1.000000 & & & & \\
\hline & $\begin{array}{c}\text { Sig. (2-tailed) } \\
\text { N }\end{array}$ & ........ & & & & \\
\hline \multirow[t]{2}{*}{ size } & Pearson Correlation & -0.021714 & 1.000000 & & & \\
\hline & $\begin{array}{l}\text { Sig. (2-tailed) } \\
\text { N }\end{array}$ & 0.6243 & & & & \\
\hline \multirow[t]{2}{*}{ Lag Sales growth } & Pearson Correlation & -0.071325 & 0.069273 & 1.000000 & & \\
\hline & $\begin{array}{l}\text { Sig. (2-tailed) } \\
\text { N }\end{array}$ & 0.1073 & 0.1178 & & & \\
\hline \multirow[t]{2}{*}{ lag RoA } & Pearson Correlation & 0.000515 & -0.268659 & -0.006179 & 1.000000 & \\
\hline & $\begin{array}{l}\text { Sig. (2-tailed) } \\
\text { N }\end{array}$ & 0.9907 & 0.0000 & 0.8892 & & \\
\hline$\overline{\text { Lag debt }}$ & $\begin{array}{c}\text { Pearson Correlation } \\
\text { Sig. (2-tailed) } \\
\text { N }\end{array}$ & $\begin{array}{c}0.002507 \\
0.9549\end{array}$ & $\begin{array}{c}-0.287013 \\
0.0000\end{array}$ & $\begin{array}{c}-0.018856 \\
0.6707\end{array}$ & $\begin{array}{c}0.899201 \\
0.0000\end{array}$ & 1.000000 \\
\hline
\end{tabular}

The coefficient of correlation between the logarithm of the variables debt ratio and return on assets (ROA) is according to Table 3 is equal to 0.899. This means the relationship among these variables is strongly significant. As the significance level is lower than $5 \%$, therefore, this relationship can be generalized into the entire population. The positive coefficient confirms a direct relation.

The coefficient of correlation between the logarithm of the variables debt ratio and sales growth is in accordance to Table 3 is equal to 0.018. This means the significance of the relation between these variables is weak. As the significance level is higher than $5 \%$, this relation cannot be generalized to the whole population.

\section{Table 4}

The results of Pearson correlation ratios

\begin{tabular}{|c|c|c|c|c|c|}
\hline Type of Industry & & & SG & $\mathrm{RO}$ & NB \\
\hline \multirow{3}{*}{ Automotive Industry } & NB & Pearson Correlation & -0.096 & $-0.573^{* *}$ & 1 \\
\hline & & Sig. (2-tailed) & 0.387 & 0.000 & \\
\hline & & $\mathrm{N}$ & 84 & 84 & 84 \\
\hline \multirow{3}{*}{ Pharmaceutical Industry } & NB & Pearson Correlation & -0.040 & $-0.556^{* *}$ & 1 \\
\hline & & Sig. (2-tailed) & 0.634 & 0.000 & \\
\hline & & $\mathrm{N}$ & 144 & 144 & 144 \\
\hline \multirow{3}{*}{ Food and Beverage } & NB & Pearson Correlation & 0.079 & -0.246 & 1 \\
\hline & & Sig. (2-tailed) & 0.550 & 0.048 & \\
\hline & & $\mathrm{N}$ & 60 & 60 & 60 \\
\hline \multirow{3}{*}{ Base Metals } & NB & Pearson Correlation & -0.071 & $0.790^{* *}$ & 1 \\
\hline & & Sig. (2-tailed) & 0.609 & 0.000 & \\
\hline & & $\mathrm{N}$ & 54 & 54 & 54 \\
\hline \multirow{3}{*}{ Nonmetallic Minerals } & NB & Pearson Correlation & $0.169^{*}$ & $-0.327^{* *}$ & 1 \\
\hline & & Sig. (2-tailed) & .058 & .000 & \\
\hline & & $\mathrm{N}$ & 137 & 138 & 138 \\
\hline \multirow{3}{*}{ Mining Industry } & NB & Pearson Correlation & -0.247 & -0.259 & 1 \\
\hline & & Sig. (2-tailed) & 0.146 & 0.127 & \\
\hline & & $\mathrm{N}$ & 36 & 36 & 36 \\
\hline \multirow{3}{*}{ Metallic Products } & NB & Pearson Correlation & 0.113 & $-0.433^{* * *}$ & 1 \\
\hline & & Sig. (2-tailed) & 0.512 & 0.008 & \\
\hline & & $\mathrm{N}$ & 36 & 36 & 36 \\
\hline \multirow{3}{*}{ Rubber Industry } & NB & Pearson Correlation & .011 & $-.325^{*}$ & 1 \\
\hline & & Sig. (2-tailed) & 0.942 & 0.024 & \\
\hline & & $\mathrm{N}$ & 48 & 48 & 48 \\
\hline \multirow{3}{*}{ Electric Devices } & NB & Pearson Correlation & -0.095 & $-0.531^{* *}$ & 1 \\
\hline & & Sig. (2-tailed) & 0.375 & 0.000 & \\
\hline & & $\mathrm{N}$ & 90 & 90 & 90 \\
\hline \multirow{3}{*}{ Paper Industry } & NB & Pearson Correlation & -.312 & $-.472^{*}$ & 1 \\
\hline & & Sig. (2-tailed) & 0.138 & 0.020 & \\
\hline & & $\mathrm{N}$ & 24 & 24 & 24 \\
\hline \multirow{3}{*}{ Miscellaneous } & NB & Pearson Correlation & -0.123 & -0.178 & 1 \\
\hline & & Sig. (2-tailed) & 0.375 & 0.199 & \\
\hline & & $\mathrm{N}$ & 54 & 54 & 54 \\
\hline
\end{tabular}


Each industry was studied by Pearson correlation test. In this research, we have only provided the coefficient of correlation between the variables debt ratio, sales growth, and return on assets for the final analysis.

\subsection{The Relation between Variables and Interpretation of Coefficients}

In this section, the main model formed from dependent, independent, and control variables is provided, and it has been fitted by normal least squares and based on the type of the data, which is panel data.

\section{Table 5}

The results of regression analysis

Dependent Variable: debt ratio

Method: Least Squares

\begin{tabular}{lllll} 
Variable & Coefficient & Std. Error & t-Statistic & Prob. \\
\hline constant & -0.155039 & 0.174112 & -0.890453 & 0.3736 \\
Sales growth & -0.024672 & 0.033607 & -0.734121 & 0.4632 \\
ROA & 0.048701 & 0.001623 & 30.01429 & 0.0000 \\
SIZE & 0.000646 & 0.006874 & 0.093974 & 0.9252 \\
volatility & -0.025332 & 0.013158 & -1.925176 & 0.0548 \\
\hline R-squared & 0.665735 & Mean dependent var & -0.437305 \\
Adjusted R-squared & 0.663093 & S.D. dependent var & 0.723499 \\
S.E. of regression & 0.419946 & Akaike info criterion & 1.112354 \\
Sum squared resid & 89.23530 & Schwarz criterion & 1.153805 \\
Log likelihood & -279.2064 & Hannan-Quinn criter. & 1.128604 \\
F-statistic & 251.9428 & Durbin-Watson stat & 1.110300 \\
Prob(F-statistic) & 0.000000 & & \\
\hline
\end{tabular}

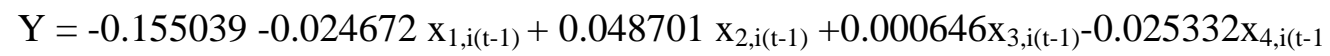

\subsection{The Interpretation of Coefficients and the Results of the Estimated Model}

The results obtained by the estimation of this model and other calculations and tests show that:

1- The statistic $t$ and its probability (Prob.) confirm the significance of the linear relationship between debt ratio and return of assessment at the confidence level of $95 \%$.

2- The statistic $R^{2}$ indicates that $66 \%$ of the changes in the dependent variables can be explained by the explanatory variable of the model. This proves that this model is considerably explainable.

3- The high value of the statistic $F$ (251.9) indicates that the entire linear regression is significant. In other words, although F statistic is high, the significance level is lower than 0.05. As a result, the model can be generalized into the whole population.

4- The Durbin-Watson statistic in this model is equal to 1.11 , and less than 2 , therefore, the correlation between errors is rejected.

5- The coefficient of the variable ROA shows that and increase in the ROA by 1 unit, can increase the debt ratio by 0.04 .

In the following table, the value of $\mathrm{t}$ for ROA is equal to 30.01429 and the Prob. less than 0.05 , and these two values confirm that there is a significant relation between ROA and debt ratio at the confidence level of $95 \%$. Therefore, the null hypothesis is rejected at the confidence level of 95\%, and a significance relation in the model can be estimated. The statistic t for the coefficient of sales growth, however, is equal to -0.734121 , and its Prob. is greater than 0.05 . Therefore, both values confirm that there is no significant relation between sales growth and debt ratio at the confidence 
level of 95\%. Thus, the null hypothesis is not rejected at the confidence level of 95\%, and no significant relation can be estimated in this model.

\subsection{The Relation between Variables of the Industrial Companies Listed on Tehran Stock Exchange}

Table 6

Test of Homogeneity of Variances

\begin{tabular}{lcccc}
\hline & Leven statistic & $\mathrm{df}_{1}$ & $\mathrm{df}_{2}$ & sig \\
\hline Lag RoA & 28.050 & 10 & 757 & 0.000 \\
Lag debt & 44.430 & 10 & 757 & 0.000 \\
Lag sales growth & 3.540 & 10 & 757 & 0.000 \\
\hline
\end{tabular}

Table 7

The results of ANOVA test

\begin{tabular}{|c|c|c|c|c|c|c|}
\hline & & Sum Of Squares & $\mathrm{df}$ & Mean Square & $\mathrm{F}$ & sig \\
\hline \multirow{3}{*}{ Lag RoA } & Between Groups & 6113.876 & 10 & 611.388 & \multirow{3}{*}{6.423} & \multirow{3}{*}{0.000} \\
\hline & Within Groups & 72058.903 & 757 & 95.190 & & \\
\hline & Total & 78172.778 & 767 & & & \\
\hline \multirow{3}{*}{ Lag debt } & Between Groups & 472868.519 & 10 & 47286.452 & \multirow{3}{*}{8.617} & \multirow{3}{*}{0.000} \\
\hline & Within Groups & 4153893.6 & 757 & 5487.310 & & \\
\hline & Total & 4626758.2 & 767 & & & \\
\hline \multirow{3}{*}{ Lag sales growth } & Between Groups & 5.100 & 10 & 0.510 & \multirow{3}{*}{1.795} & \multirow{3}{*}{0.058} \\
\hline & Within Groups & 214.831 & 756 & 0.284 & & \\
\hline & Total & 219.931 & 766 & & & \\
\hline
\end{tabular}

To study whether the variables of return on assets, sales growth, and debt ratio depend on the type of industry, analysis of variance (ANOVA) has been applied. Considering that the significance value of the factor of industry for sales growth is equal to 0.058 , we can conclude that the factor of industry is not effective in this variable. In contrast, the significance of the industry factor for sales growth is equal to 0.058 and it indicates that industry has no effect on this variable. Considering that, the significance of industry is lower than 0.05 in the variables of return on assets and debt ratio, therefore, the factor of industry is considered effective in these variables.

\section{Conclusion}

In this section, the information obtained from the previous sections are used to test the hypotheses, and provide the following conclusion.

Hypothesis 1: There is a relation between debt ratio and sales growth.

To evaluate the normality of the above-mentioned variables, the Kolmogrov-Smirnov test has been applied, and as the variables were not normal at first, the logarithm of the model was used.

In the study of the dependent variable debt ratio, the statistic $t$ and its probability value (equal to 0.4632) show that there is no significant linear relation between this dependent ratio and sales growth at the confidence level of 95\%. As the value of significance level $\mathrm{F}$ in this model is equal to 0.000 , therefore, it is concluded that the linear regression is significant and can be generalized into the total population. Moreover, it can be concluded that the first hypothesis, i.e. the relation between debt ratio and sales growth, is rejected.

Hypothesis 2: There is a relation between debt ratio and return on assets.

To evaluate the normality of the above-mentioned variables, the Kolmogrov-Smirnov test has been applied, and as the variables were not normal at first, the logarithm of the model was used.

In the study of the dependent variable debt ratio, the statistic t and its probability value (equal to 0.000 ) indicate that the significant linear relation between debt ratio and return on assets can be generalized to the whole population at the confidence level of 95\%. The coefficient of return on assets in the model is equal to 0.048701 , and its shows that there is a significant and direct relation 
between debt ratio and return on assets. The coefficient of determination (R2) obtained for this hypothesis is equal to 0.66 , which indicates that $66 \%$ of the changes in the dependent variables can be explained by the explanatory variable of the model. It must be noted that this percentage confirms the high explain ability of this model. As the significance value $\mathrm{F}$ in this model is equal to 0.000 , it can be concluded that the linear regression is of significance and the model can be generalized into the whole population. Considering the above-mentioned issues, it can be concluded moreover that the second hypothesis, i.e. the relation between debt ratio and return on assets, is confirmed.

\section{References}

Namazi, Mohammad \& Shirzadeh. (Winter 2005). A Study of the Relation between Capital Structure and Return on Assets of the Companies listed on Tehran Stock Exchange. Journal of Accounting and Auditing Studies, 42, 75 - 95.

Yazdani, N. (1991). A Study of the Factors Effective and Decisive in the Financial Structure of the Companies listed on Tehran Stock Exchange. Unpublished Master Dissertation in the Field of Business Management submitted to the University of Isfahan.

Bolton, P., \& Scharfstein, D.S. (1990) A theory of predation based on agency problems in financial contracting. American Economic Review, 80(1), 93-106.

Brander, J.A., \& Lewis, T.R. (1986) Oligopoly and financial structure: the limited liability effect. American Economic Review, 76(5), 956-970.

Campello, M. (2003) Capital structure and product markets interactions: evidence from business cycles. Journal of Financial Economic, 68, 353-378.

Campello, M. (2006). Debt financing: does it boost or hurt firm performance in product markets? Journal of Financial Economic, 82, 135-172.

Campello, M. (2007). Asset tangibility and firm performance under external financing: evidence from product markets (FEN Working Paper). Available at SSRN: $\underline{\text { http:www.ssrn.com.abstract }=971170}$

Chen, S.S., Chung, T.Y., Ho, K.W., \& Lee, C.F. (2007). Intra-Industry Effects of Delayed New Product Introductions. Review of Pacific Basin Financial Markets and Policies, 10(3), 415-443.

Chevalier, J.A. (1995a). Capital structure and product-market competition: empirical evidence from thesupermarket industry. American Economic Review, 85(3), 415-435.

Chevalier, J.A. (1995b). Do LBO supermarkets charge more? An empirical analysis of the effects of LBOs onsupermarket pricing. Journal of Finance, 50(4), 1095-1112.

Glazer, J. (1994). The strategic effects of long-term debt in imperfect competition. Journal of Economic Theory, 62, 428-443.

Istaitieh, A., \& Rodriguez, J.M. (2002). Stakeholder theory, market structure, and firm's capital structure: An empirical evidence (FEN Working Paper). Available at SSRN: http:..ssrn.com.abstract $=413661$.

Istaitieh, A., \& Rodriguez, J.M. (2003). Financial leverage interaction with firm's strategic behaviour: an empirical analysis (FEN Working Paper). EFMA 2003 Helsinki Meetings. Available at SSRN: http:..ssrn.com.abstract=393220.

Kovenock, D., \& Phillips, G.M. (1995). Capital structure and product-market rivalry: how do we reconcile theory and evidence? American Economic Review, 85(2), 403-408.

Kovenock, D., \& Phillips, G.M. (1997). Capital structure and product market behaviour: an examination of plant exit and investment decisions. Review of Financial Studies, 10(3), 767-803.

Low, P. Y., \& Chen, K. H. (2004). Diversification and capital structure: Some international evidence. Review of Quantitative Finance and Accounting, 23(1), 55-71.

Opler, T.C., \& Titman, S. (1994) Financial distress and corporate performance. Journal of Finance, 49(3), 1015-1040.

Phillips, G.M. (1995). Increased debt and industry product markets: an empirical analysis. Journal of Financial Economics, 37, 189-238.

Titman, S., \& Wessels, R. (1988). The determinants of capital structure choice. Journal of Finance, 43(1), 1-19. 
1306

Zingales, L. (1998). Survival of the fittest or the fattest? Exit and financing in the trucking industry. Journal of Finance, 53(3), 905-938. 